\title{
GSK3 $\beta$ mediates pancreatic cancer cell invasion in vitro via the CXCR4/MMP-2 Pathway
}

\author{
Xu Ying ${ }^{1+}$, Li Jing ${ }^{2 \dagger}$, Shijie Ma ${ }^{1}$, Qianjun $\mathrm{Li}^{1}$, Xiaoling Luo ${ }^{1}$, Zhenguo Pan', Yanling Feng ${ }^{1}$ and Pan Feng ${ }^{\text {* }}$
}

\begin{abstract}
Background: Glycogen synthase kinase-3 3 (GSK3 $\beta$ ) expression and activity are upregulated in pancreatic cancer tissues. In our previous study, we found that stromal cell-derived factor-1/ chemokine receptor C-X-C motif chemokine receptor 4 (SDF-1a/CXCR4) upregulated matrix metalloproteinase 2 (MMP-2) and promoted invasion in PANC1 and SW-1990 pancreatic cancer cells by activating p38 mitogen-activated protein kinase (p38 MAPK). Additionally, inhibition of GSK3 $\beta$ reduced MMP-2 secretion.

Methods: To investigate the molecular mechanism of GSK3 $\beta$ in pancreatic cancer tissues, we created stable PANC1 cells up-regulation of GSK3 $\beta$ by transfecting GSK3 $\beta$ overexpression plasmid, and down-regulation of GSK3 $\beta$ using two different types of RNA interference.

Results: Western blotting showed that overexpression of GSK3 $\beta$ up-regulated CXCR4 and MMP-2 expression; suppression of GSK3 $\beta$ down-regulated CXCR4 and MMP-2 protein expression. Up-regulation of MMP2 induced by overexpression of GSK3 $\beta$ was blocked by inhibition of CXCR4. Overexpression of GSK3 $\beta$ promoted PANC1 cell invasion, and down-regulation of GSK3 $\beta$ suppressed PANC1 cell invasion in the transwell invasion assays. However, inhibition of CXCR4 using shRNA attenuated the ability of GSK3 $\beta$ to promote PANC1 cell invasion.

Conclusions: This study demonstrated that GSK3 $\beta$ promotes PANC1 cell invasion via the CXCR4/MMP-2 pathway.
\end{abstract}

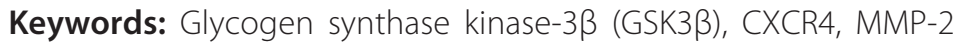

\section{Background}

Pancreatic cancer is one of the most aggressive human cancers worldwide. Despite the introduction of improved and/or combined treatments such as surgery, chemotherapy and radiation therapy, the prognosis of patients with pancreatic cancer remains poor. Novel, effective therapeutic strategies are urgently required to improve the prognosis of patients with this malignancy. Improvements to chemotherapy strategies require the development of novel target-directed therapies. Therefore, further studies are needed to identify novel molecular therapeutic targets which determine the sensitivity of pancreatic cells to chemotherapeutic agents and ionizing radiation [1].

\footnotetext{
* Correspondence: fengliupan@126.com

${ }^{\dagger}$ Equal contributors

'Department of Gastroenterology, Huai'an First People's Hospital, Nanjing Medical University, 6 Beijing Road West, Huai'an, Jiangsu 223300, People's Republic of China

Full list of author information is available at the end of the article
}

The serine/threonine kinase glycogen synthase kinase-3 (GSK3) was originally identified as a regulator of glycogen synthesis $[2,3]$. GSK3 $\beta$ phosphorylates and inactivates the enzyme glycogen synthase. However, GSK3 $\beta$ is also involved in diverse cellular processes such as cell proliferation, apoptosis, invasion and inflammation. Altered GSK3 $\beta$ expression is associated with numerous pathological processes, including type 2 diabetes, Alzheimer's disease, and cancer [4-7]. Recent studies suggested that GSK3 $\beta$ can promote the invasion of pancreatic, lung, breast and liver cancer cells, and inhibition of GSK3 $\beta$ induces apoptosis [8-10]. These results have led researchers to propose GSK3 $\beta$ as a potential therapeutic target in cancer. Recent studies have also indicated that GSK3 $\beta$ promotes the proliferation and invasion of pancreatic cancer cells. Inhibition of GSK3 $\beta$ triggered an apoptotic response in pancreatic cancer cells via a JNK-dependent mechanism [11], and attenuated cell survival and proliferation and induced apoptosis in pancreatic cancer cell lines [5].
C Biomed Central

(c) 2015 Ying et al. This is an Open Access article distributed under the terms of the Creative Commons Attribution License (http://creativecommons.org/licenses/by/4.0), which permits unrestricted use, distribution, and reproduction in any medium, provided the original work is properly credited. The Creative Commons Public Domain Dedication waiver (http:// creativecommons.org/publicdomain/zero/1.0/) applies to the data made available in this article, unless otherwise stated. 
Chemokine receptor $\mathrm{C}-\mathrm{X}-\mathrm{C}$ motif chemokine receptor 4 (CXCR4) and its natural ligand stromal cellderived factor-1 (CXCL12, SDF-1) play a role in a variety of physiological and pathological processes, including cell proliferation, migration and invasion [12]. Matrix metalloproteinase 2 (MMP-2) promotes the invasion of a variety of cancer cells, including pancreatic cancer cells [13]. SDF-1/CXCR4 and MMP-2 are overexpressed in pancreatic cancer tissues, and have been found to act as prognostic markers in various types of cancer, including pancreatic cancer. SDF-1/ CXCR4 are thought to promote pancreatic cancer cell invasion by upregulating the expression and activity of MMP-2 [14-17]. Inhibition of GSK3 $\beta$ enhanced Mesenchymal stromal cells (MSCs) migration by increasing expression of CXCR4 [18]. SDF1/CXCR4 had effect on resident c-kit(+) CSPCs by increasing GSK3 $\beta$ activity [19]. Silencing of GSK3 $\beta$ decreased CXCL12 expression (the ligand of CXCR4) [20].
Here, we investigated the relationship between GSK3 $\beta$ and CXCR4/MMP-2 in pancreatic cancer cells, in order to further characterize the cellular and molecular mechanisms involved in pancreatic cancer.

\section{Results}

Overexpression of GSK3 $\beta$ upregulates CXCR4 and MMP-2 To elucidate the effect of GSK3 $\beta$ on the expression of CXCR4 and MMP-2 in pancreatic cancer cells, we overexpresses GSK3 $\beta$ in PANC1 and SW-1990 cells. Fig. 1a show that, compared to control PANC1 cells and vector control cells, GSK3 $\beta$ expression increases by about 2.3 -fold in the stable cell clone; this clone is used as a cellular model of GSK3 $\beta$ overexpression in the remainder of the study.

We determine the expression of CXCR4 and MMP2 in PANC1 cells overexpressing GSK3 $\beta$ using Western blotting. Overexpression of GSK3 $\beta$ upregulates

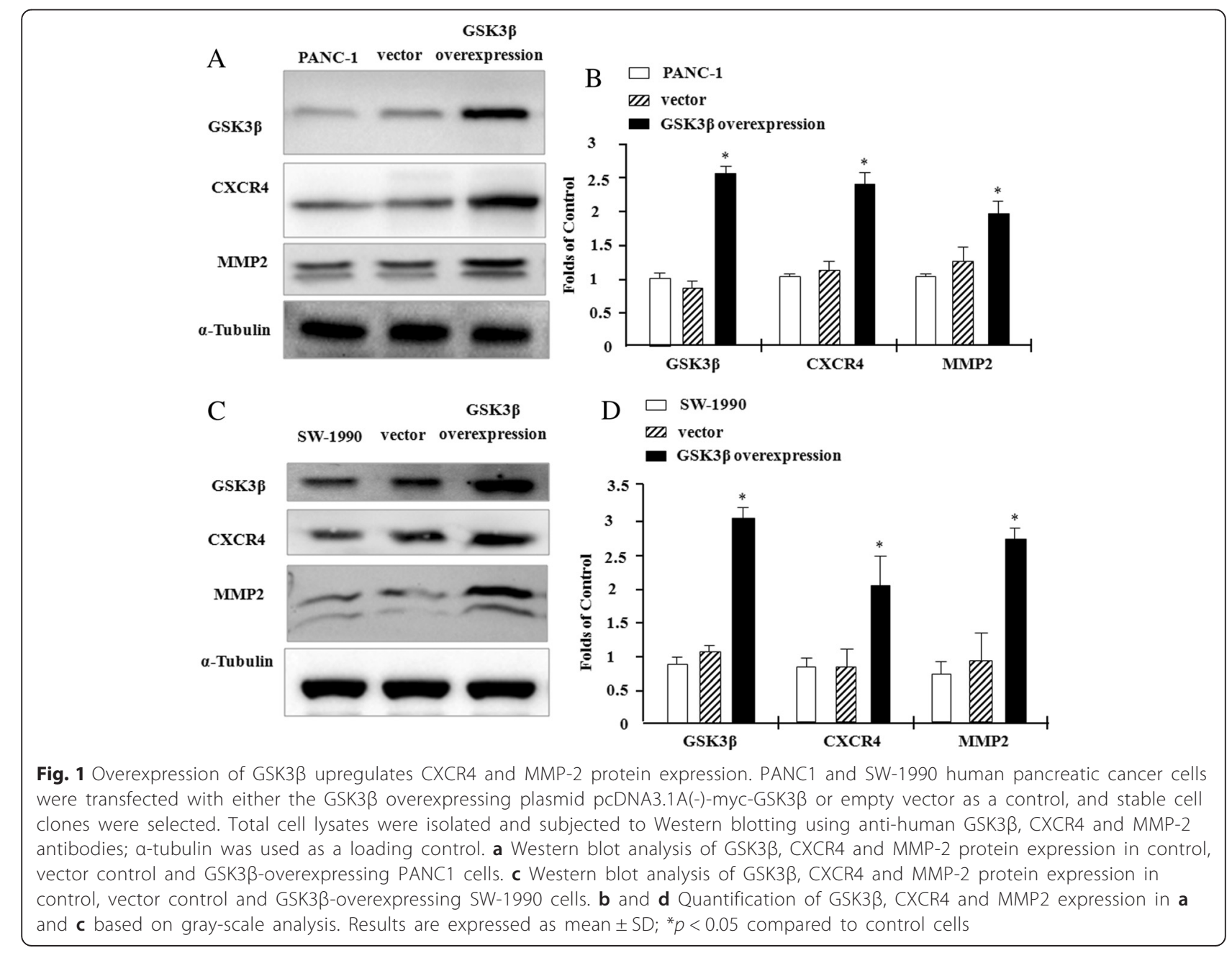


CXCR4 and MMP-2 expression by about 2.4- and 2.1-fold, respectively, compared to control PANC1 cells and vector control cells (Fig. $1 \mathrm{~b}$ and Additional file 1: Figure S2A). And the same phenomenon was aslo observed in SW-1990 cells (Fig. 1c and d).

\section{Inhibition of GSK3 $\beta$ downregulates CXCR4 and MMP-2 expression}

Furthermore, we assesse whether inhibition of GSK3 $\beta$ affected CXCR4 and MMP-2 expression in PANC1 and SW-1990 cells. Using two different types of RNA interference, GSK3 $\beta$ expression is successfully down-regulated (Fig. 2a and b). Scrambled shRNA is used as a control. Suppression of GSK3 $\beta$ expression significantly reduces CXCR4 and MMP-2 expression approximately 2.3 folds and 5.8 folds in PANC1 cells, compared to scrambled control cells (Fig. 2a, b and Additional file 1: Figure S2B). And the same phenomenon was aslo observed in SW-1990 cells (Fig. 2c and d). We also detected the effect of GSK3 $\beta$ inhibition on the expression of CXCR4 and activity of downstream signaling molecular $\beta$-catenin using GSK3- specific inhibitor AR-A014418. Additional file 2: Figure S1 showed that inhibition of GSK3 $\beta$ downregulated CXCR4 expression and suppressed phosphorylation of $\beta$-catenin.

\section{GSK3 $\beta$ promotes PANC1 cell invasion}

We examine the effect of GSK3 $\beta$ on cell invasion in PANC1 cells using the in vitro cell invasion assay. As shown in Fig. 3a and b, the cell invasion assay demonstrates that overexpression of GSK3 $\beta$ promoted the invasion of PANC1 cells compared to vector control cells; suppression of GSK3 $\beta$ decreases the invasion of PANC1 cells compared to the scrambled cells. These results indicate that GSK3 $\beta$ induces PANC1 cell invasion.

PANC1 cell invasion induced by overexpression of GSK3 $\beta$ is attenuated by suppression of CXCR4

MMP-2 degrades the extracellular matrix, which promotes cancer cell invasion, and we previousl [21] found that CXCR4 promoted human cancer cell invasion by upregulating MMP-2. In this study, we observe that GSK3 $\beta$ regulated CXCR4 and MMP-2 expression (Figs. 1 and 2).

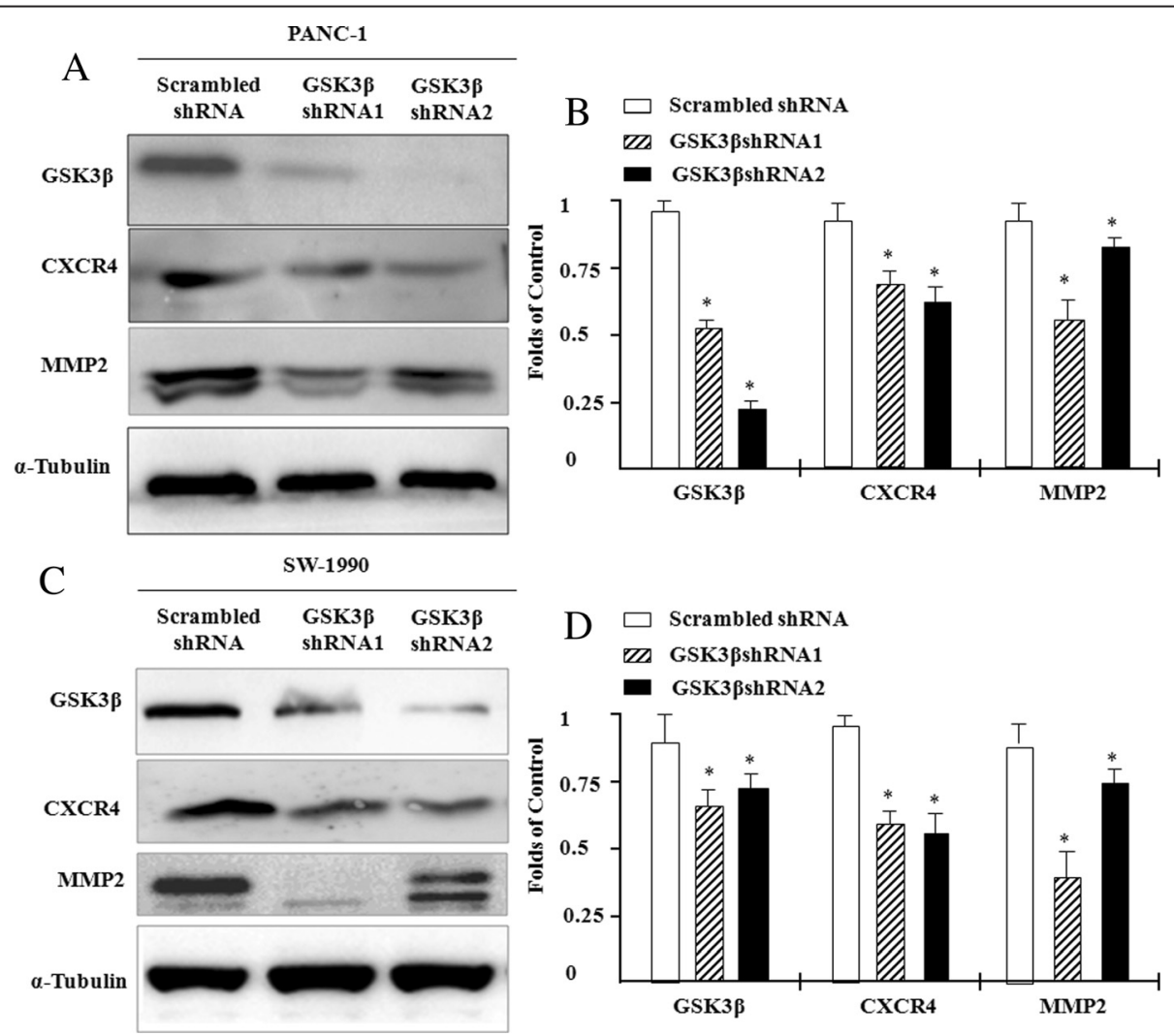

Fig. 2 Inhibition of GSK3 $\beta$ downregulates CXCR4 and MMP2 expression. PANC1 and SW-1990 human pancreatic cancer cells were transfected with the GSK3 $\beta$ silencing plasmid pCDNA6.2-GW/EmGFP-miR-GSK3 $\beta$ expression vector, or scrambled vector as a control, and stable cell clones were selected. Total cell lysates were isolated and subjected to Western blotting using anti-human GSK3 $\beta$, CXCR4 and MMP-2 antibodies; $a$-tubulin was used as a loading control. a GSK3 $\beta$, CXCR4 and MMP-2 protein expression in PANC1 cells. (C) GSK3ß, CXCR4 and MMP-2 protein expression in SW-1990 cells. b and d Quantification of GSK3 3, CXCR4 and MMP-2 expression in a and $\mathbf{c}$ based on gray-scale analysis. Results are expressed as the mean \pm SD; ${ }^{*} p<0.05$ compared to control cells 


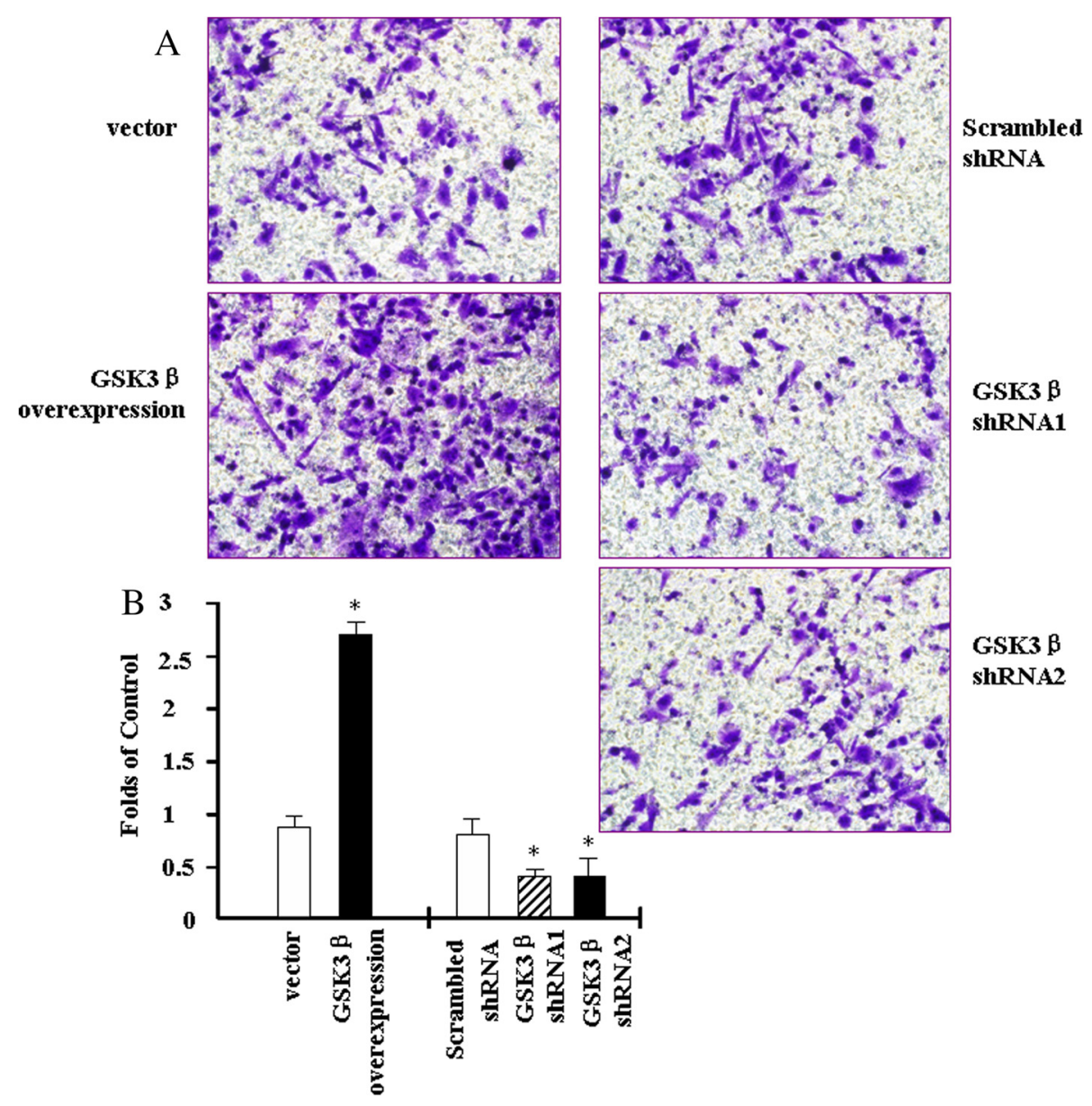

Fig. 3 GSK3 $\beta$ promotes PANC1 human pancreatic cancer cells invasion. Transwell invasion assay was employed to determine the effect of GSK3 $\beta$ on cell invasion. Stable cell clones of PANC1 cells overexpression or suppression of GSK3 $\beta$ were selected. $200 \mu$ l cell suspension maitained in serum-free DMEM/0.1 \% BSA were added to the matrigel-coated upper compartment, the DMED/10\%FBS medium was added to the lower compartment, and the plates were incubated for $48 \mathrm{~h}$ at $37^{\circ} \mathrm{C}$. a After incubation for $48 \mathrm{~h}$, the upper surface of the filter was scrubbed free of cells, the filter was fixed and stained and the lower surface was photographed (200x original magnification). b Quantification of A. Results are expressed as the mean \pm SD; ${ }^{*} p<0.05$ compared to control cells

Therefore, we investigated whether GSK3 $\beta$ regulated MMP-2 expression and cell invasion via CXCR4 signaling. To determine the effect of CXCR4 on cell invasion induced by GSK3 $\beta$ overexpression, PANC1 cells overexpression GSK3 $\beta$ were transfected with the CXCR4 silencing plasmids, or scrambled vector as a control, and stable cell clones were selected. Western blotting result showes that CXCR4 protein is successfully suppressed (Fig. 4a and b).

As shown in Fig. 4a and b, up-regulation of MMP-2 induced by overexpression of GSK3 $\beta$ is attenuated by the CXCR4 inhibition using transfecting with CXCR4 shRNA plasmids. Fig. 4c shows that overexpression of GSK3 $\beta$ also increased the invasion of PANC1 cells compared to the control cells. However, the ability of GSK3 $\beta$ to promote cell invasion is reduced by the CXCR4 inhibition. These results indicate that GSK3 $\beta$ induces MMP-2 expression and cell invasion via a CXCR4-dependent mechanism in PANC1 cells.

\section{Discussion}

Among the current range of novel target molecules, GSK3 $\beta$ has emerged as a therapeutic target in pancreatic cancer $[8,22,23]$. GSK3 $\beta$ expression and activity are upregulated in pancreatic cancer [24-28]. In spite of this evidence, the precise role of GSK3 $\beta$ and its potential as a therapeutic target in pancreatic cancer still require further research. The focus of this study was to determine the effects of GSK3 $\beta$ and investigate its molecular mechanism of action, specifically via the GSK3 $\beta$-CXCR4/ MMP-2 pathway, in PANC1 pancreatic cancer cells.

Previous studies have shown that inhibition of GSK3 $\beta$ reduced the proliferation and survival of pancreatic cancer cells, which was associated with decreased cyclin D1 


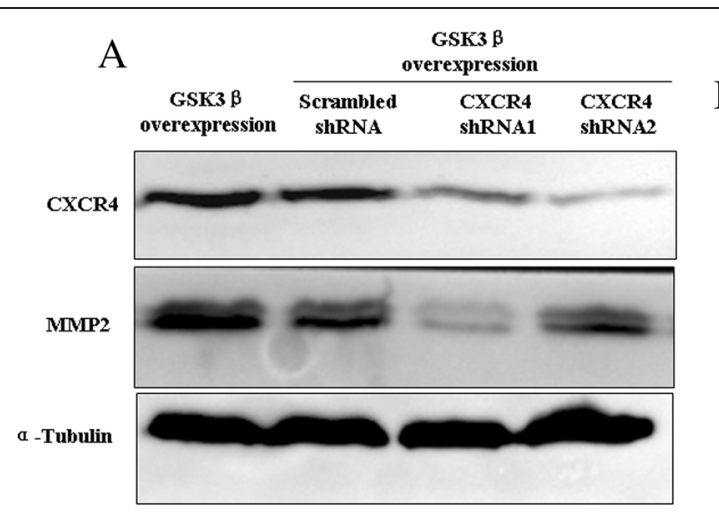
$\mathrm{B} \square$ GSK3 $B$ overexpression
- GSK3 $\beta$ overexpression+ Scrambled shRNA
ZZZ GSK3 B overexpression + CXCR4 ShRNA1 GSK3 3 overexpression + CXCR4 shRNA2

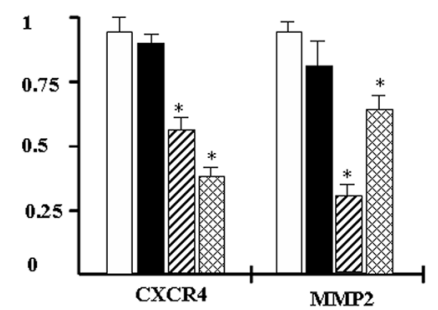

C

GSK3 $\beta$
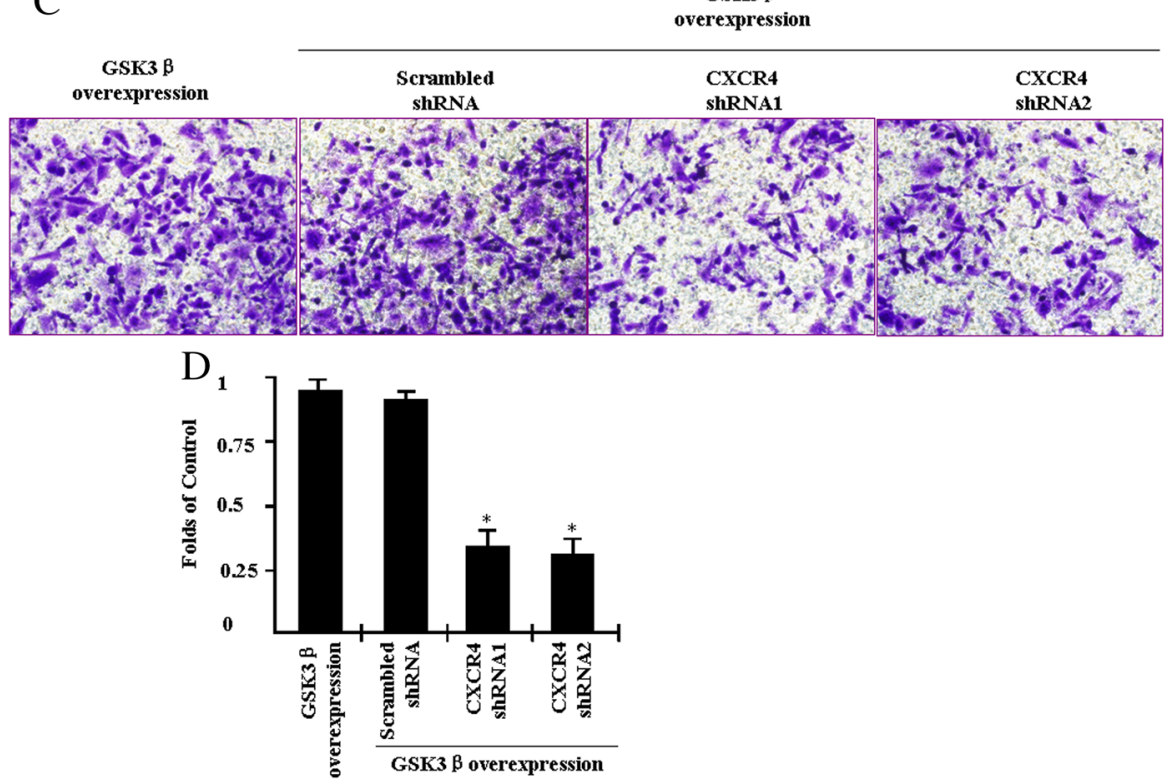

Fig. 4 Overexpression of GSK3 $\beta$ promotes PANC1 cell invasion and MMP-2 expression via a CXCR4-dependent mechanism. To determine the effect of CXCR4 on cell invasion induced by GSK3 $\beta$ overexpression, PANC1 cells overexpression GSK3 $\beta$ were transfected with the CXCR4 silencing plasmids, or scrambled vector as a control, and stable cell clones were selected. a Total cell lysates were isolated and subjected to Western blotting using anti-MMP-2 and anti-CXCR4-antibodies; a-tubulin was used as a loading control. b Quantification of CXCR4 and MMP-2 expression in a based on gray-scale analysis. c Transwell invasion assay was employed to determine the effect of CXCR4 on PANC1 cells invasion induced by GSK3 $\beta$ overexpression. $\mathbf{d}$ Quantification of A. Results are expressed as the mean \pm SD; ${ }^{*} p<0.05$ compared to control cells

expression, $\mathrm{Rb}$ phosphorylation and secretion of matrix metalloproteinase-2 (MMP-2) [26, 29, 30]. Inhibition of GSK3 $\beta$ also suppressed pancreatic cancer growth and angiogenesis by decreasing the expression of Blc-2 and vascular endothelial growth factor (VEGF), and abrogating $\mathrm{NFK}_{\mathrm{K}} \mathrm{B}$ activity $[17,31]$. GSK3 $\beta$ also maintained constitutive $\mathrm{NF}_{\mathrm{K}} \mathrm{B}$ signaling in pancreatic cancer cells $[9,32-34]$. The GSK3 $\beta / \beta$-catenin pathway has also been linked to pancreatic cancer [35]. These results led us to propose GSK3 $\beta$ as a potential therapeutic target in pancreatic cancer; therefore, further studies on the molecular mechanism of action of GSK3 $\beta$ are required. The effect of GSK3 $\beta$ on SDF-1/CXCR4 is complicated. Kim YS et al. sugguested that inhibition of GSK3 $\beta$ upregulated expression of CXCR4 but Tamura $M$ et al. said that silencing of GSK3 $\beta$ decreased SDF-1 expression $[18,20]$. SDF-1 might increase GSK3 $\beta$ phosphorylation [19]. SDF-1/CXCR4 aslo mediated GSK3 $\beta$-induced physiological migration of stem cells [36]. Activation of CXCR4-mediated cell signal resulted in the inhibition of GSK3 3 [37].

In our previous study [21], we found that SDF-1 $\alpha /$ CXCR4 upregulated MMP-2 expression and induced the invasion of PANC1 and SW-1990 pancreatic cancer cells by activating p38 MAPK. Additionally, inhibition of GSK3 $\beta$ reduced the secretion of MMP-2 [26]. These results shed light on the molecular mechanism of action of GSK3 $\beta$ in pancreatic cancer. In this study, we 
demonstrated that GSK3 $\beta$ induced PANC1 pancreatic cancer cell invasion via the CXCR4/MMP-2 pathway.

\section{Conclusions}

This study provides further insight into the molecular mechanism of GSK3 $\beta$-induced pancreatic cancer invasion, and will allow exploration of novel therapeutic strategies for pancreatic cancer that target GSK3 $\beta$ and/ or CXCR4/MMP-2.

\section{Materials and methods \\ Reagents}

Dulbecco's modified Eagle's medium (DMEM; \#11965084) was purchased from Life Technologies ${ }^{\mathrm{TM}}$ (USA). The $\alpha$-Tubulin antibody (\#T5168) and AR-A014418 (\#487021$52-3$, an inhibitor of GSK3) were purchased from SigmaAldrich (USA). Antibodies against GSK3 3 (\#9315) and MMP-2 (\#4022) were purchased from Cell Signaling Technology (USA). Antibodies against CXCR4 (\#ab2074) was purchased from Abcam.

\section{Cell culture}

The human pancreatic cancer cell line PANC1 (CRL1469) and SW-1990 (CRL-2172), which was established from human pancreatic cancer ducts, was purchased from the American Type Culture Collection (ATCC, Manassas, VA, USA). PANC1 cells were cultured in Dulbecco's modified Eagle's medium (DMEM) supplemented with $10 \%$ fetal bovine serum, $100 \mathrm{U} / \mathrm{ml}$ penicillin and $100 \mathrm{mg} /$ $\mathrm{ml}$ streptomycin sulfate, and maintained at $37^{\circ} \mathrm{C}$ in a $5 \%$ $\mathrm{CO}_{2}$ humidified incubator.

\section{Construction of GSK3 $\beta$ overexpressing plasmid and generation of stable clones}

The overexpressing plasmid pcDNA3.1A(-)-myc-GSK3 $\beta$ was constructed as follows: full-length human GSK3 $\beta$ cDNA was amplified by RT-PCR from mRNA isolated from human white adipose tissue. The primer sequences were: forward, 5'-CGTGAATTCATCATGTCAGGGCG GCCCA -3' and reverse, 5'-GCTGTCGACG GGATCCG TCAGGTGGAGTTGGA-3'. The PCR product was cloned into the expression vector pcDNA3.1A(-)-myc, and then transfected into PANC1 cells using $\mathrm{X}$ tremeGENE HP DNA Transfection Reagent. At $48 \mathrm{~h}$ after transfection, the cells were cultured in selection

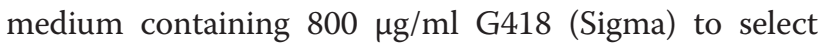
resistant colonies for further analysis.

\section{Construction of miRNA-GSK3 $\beta$ expression plasmids and stable clone selection}

Two distinct domains within the coding region of the human GSK3 $\beta$ cDNA were targeted for RNA interference. For this purpose, two pairs of reverse complementary oligonucleotides were designed and synthesized as Table 1. The oligonucleotides were annealed and inserted into the pcDNA6.2-GW/EmGFP-miR expression vector (Invitrogen, \#K4936-00) to create GSK3 $\beta$ shRNA1 and shRNA2. A control scrambled shRNA was also created. We used X-tremeGENE HP DNA Transfection Reagent to separately transfect the three kinds of plasmids into PANC-1. At $48 \mathrm{~h}$ after transfection, the cells were cultured in selection medium containing $800 \mu \mathrm{g} / \mathrm{ml} \mathrm{G} 418$ (Sigma) to select resistant colonies for further analysis. CXCR4 shRNA plasmids are gifts from the Department of Gastroenterology, The First Affiliated Hospital of Nanjing Medical University [38].

\section{Western blotting analysis}

PANC1 cells were lysed using RIPA buffer. Equal amounts of protein $(60 \mu \mathrm{g})$ were separated on $10 \%$ SDS-PAGE gels and transferred to Immobilon-P membranes (Millipore, Bedford, MA, USA). The membranes were probed overnight at $4{ }^{\circ} \mathrm{C}$ with antibodies against GSK3 $\beta$, CXCR4 or MMP-2 in TBST containing $1 \%(w / v)$ BSA, incubated with the appropriate anti-rabbit or anti-mouse secondary antibodies for $2 \mathrm{~h}$, and immune complexes were detected using the ECL plus detection kit (Pierce, Rockford, IL, USA) and quantified using a scanning densitometer and molecular analysis software (Bio-Rad, Hercules, CA, USA).

\section{Cell invasion assay}

PANC1 cell invasion was assayed using 24-well Transwell plates (Corning Costar, Schiphol-Rijk, Netherlands). ECM gel solution $(60 \mu \mathrm{l})$ was added to the top compartment of each cell culture insert and dried overnight in a laminar flow cabinet. PANC1 cells were washed twice with phosphate-buffered saline (PBS), resuspended in serumfree DMEM containing $0.1 \% \mathrm{BSA}$, and adjusted to a final

Table 1 Reverse complementary oligonucleotides

\begin{tabular}{ll}
\hline Oligo & $5^{\prime}$ to 3 \\
\hline $1-\mathrm{F}$ & TACATAGTAAGTGGGCCTTCAGGCGCCTTTtGCGGTTTGACTGATGCTCTGAACTGCCGGCCTA \\
$1-\mathrm{R}$ & AGTGTAGTACTAGAGAACAGGCTAGGGAGTTGGCCCCAACCACTGCCTGTTCTGTCCTTGCTC \\
$2-\mathrm{F}$ & GAAGAGGCAGGGATCAGTAGCGTAGGGTTAAAACACTGACTGCTGCCTAGTTACTCCACTGAA \\
$2-\mathrm{R}$ & GCCAACAGTGTTGAGCTAGGGACCGGTCAAACAGGCCAAAGCCTCCTAGCTACTTCCGGTTCC \\
Scrambled-F & TGTCTGAACATACTGCCTGAGAGACGTTCTGACCACTAAGAACGTCTCTGAACAGTACTGAT \\
Scrambled-R & TACTAAAGTCAACTGCGAAGGAGAAGTCAGTTGAGGCCCAGAACGTAGCCACGCTTACTACTA \\
\hline
\end{tabular}


concentration of $1 \times 10^{6}$ cells $/ \mathrm{ml}$. Serum-free DMEM/ $0.1 \%$ BSA $(600 \mu \mathrm{l})$ and $200 \mu \mathrm{l}$ cell suspension were added to the matrigel-coated upper compartment, and the same medium was added to the lower compartment, and the plates were incubated for $48 \mathrm{~h}$ at $37{ }^{\circ} \mathrm{C}$. Cells remaining on the upper side of the filter were removed by gentle wiping, and cells that had migrated through the filter were counted using a light microscope (six fields were counted in each chamber for each condition; $200 \times$ magnification).

\section{Statistical analysis}

Data were analyzed by two-tailed Student $t$ test for single comparisons and by one-way analysis of variance for multiple group comparisons. Differences were considered significant at ${ }^{*} p<0.05$ versus control.

\section{Additional files}

Additional file 1: Figure S2. The transcript levels for CXCR4 and MMP2 were quantified by real-time quantitative transcription polymerase chain reaction (real-time PCR). Total RNA of PANC-1 cells were extracted by TRIzol reagent (Invitrogen) and $1 \mu \mathrm{g}$ total RNA was used for reverse transcription to CDNA according to the manufacturer's instructions. The CDNA aliquots were used for quantification of mRNA by real-time PCR using ABI Prism 7000 sequence detection system (Applied Biosystems, Foster City, CA), using SYBR Green PCR master mix (Applied Biosystems). All data were analyzed using $\beta$-actin gene expression as an internal standard. The specific primers were as follows: $\beta$-actin forward: $5^{\prime}$-TCACCAA CTGGGACGACAT-3', and reverse: 5'-GCACAGCCTGGATAGCAAC-3', CXCR4 (NM_001008540.1) forward: 5'-CGAGGCCCTAGCTTTCTTCC-3', and reverse: 5'-GAGGATCTTGAGGCT GGACC-3', MMP2

(NM_001302509.1) forward: 5'-GGATGGCAAGTACGGCTTCT-3', and reverse: 5'-GTT CCCACCAACAGTGGACA-3'. The thermal cycler was programmed as: denaturation at $95{ }^{\circ} \mathrm{C}$ for $5 \mathrm{~min}$, followed by 33 cycles at $95^{\circ} \mathrm{C}$ for $30 \mathrm{~s}$ and annealing at $60{ }^{\circ} \mathrm{C}$ for $\beta$-actin, $60{ }^{\circ} \mathrm{C}$ for CXCR4, and $56^{\circ} \mathrm{C}$ for MMP2 for $30 \mathrm{~s}$, extension in all was carried at $72^{\circ} \mathrm{C}$ for $1 \mathrm{~min}$, with a final extension step of $10 \mathrm{~min}$. (A) Overexpression of GSK3B upregulates CXCR4 and MMP-2 expression respectively, compared to control PANC1 cells and vector control cells. (B) Suppression of GSK3ß expression significantly reduces CXCR4 and MMP-2 expression approximately 2.3 folds and 5.8 folds in PANC1 cells, compared to scrambled control cells.

Additional file 2: Figure S1. Effect of GSK3 inhibition on phosporylation of $\beta$-catenin and CXCR4 expression. The levels of phosphorylation of $\beta$-catenin and CXCR4 expression were examined by Western blotting in pancreatic cancer cells PANC-1 after treatment with $10 \mu \mathrm{M}$ AR-A014418 (AR) (\#487021-52-3, an inhibitor of GSK3, was purchased from Sigma-Aldrich (USA)) for 6 hous. Expression of CXCR4 and $\beta$-catenin and its phosphorylation ( $p$ - $\beta$-catenin S33/37/ T41) (Phospho- $\beta$-catenin (Ser33/37/Thr41) \#9561 antibody and $\beta$-catenin antibody \#9562 were purchased from CST) were examined and compared between the same pancreatic cancer cells treated with DMSO or AR-A014418.

\section{Abbreviations}

GSK3ß: Glycogen synthase kinase-3ß; CXCR4: Chemokine receptor C-X-C motif chemokine receptor 4; MMP-2: Matrix metalloproteinase 2; SDF-1: Stromal cell-derived factor-1.

\section{Competing interests}

The authors declare that they have no competing interests.

\section{Authors' contributions}

$X Y, L J$, and SM conducted the molecular studies, and carried out the data collection; QL, XL, ZP, and YF conducted part of the molecular studies, and wrote this paper; and PF designed this study. All authors read and approved the final manuscript.

\section{Acknowledgments}

This work was supported by grants from Science and Technology Support Program of Huaian (No.HAS2010023).

\section{Author details}

'Department of Gastroenterology, Huai'an First People's Hospital, Nanjing Medical University, 6 Beijing Road West, Huai'an, Jiangsu 223300, People's Republic of China. 'Department of Hepatology, Huai'an Fourth People's Hospital, No.128, Yan an East Road, Qing pu District, Huai'an, Jiangsu 223300, People's Republic of China.

Received: 21 August 2014 Accepted: 9 June 2015

Published online: 05 July 2015

\section{References}

1. Tamburrino A, Piro G, Carbone C, Tortora G, Melisi D. Mechanisms of resistance to chemotherapeutic and anti-angiogenic drugs as novel targets for pancreatic cancer therapy. Front Pharmacol. 2013;doi: 10.3389/fphar.2013.00056.

2. Klamer $\mathrm{G}$, Song $\mathrm{E}, \mathrm{Ko} \mathrm{KH}, \mathrm{O}$ 'Brien TA, Dolnikov A. Using small molecule GSK3 $\beta$ inhibitors to treat inflammation. Curr Med Chem. 2010;17(26):2873-81.

3. Mishra R. Glycogen synthase kinase 3 beta: can it be a target for oral cancer Mol Cancer. 2010;9:144.

4. Bilim V, Ougolkov A, Yuuki K, Naito S, Kawazoe H, Muto A, et al. Glycogen synthase kinase-3: a new therapeutic target in renal cell carcinoma. Br J Cancer. 2009;101(12):2005-14.

5. Mai W, Kawakami K, Shakoori A, Kyo S, Miyashita K, Yokoi K, et al. Deregulated GSK3\{beta\} sustains gastrointestinal cancer cells survival by modulating human telomerase reverse transcriptase and telomerase. Clin Cancer Res. 2009;15(22):6810-9.

6. Naito S, Bilim V, Yuuki K, Ugolkov A, Motoyama T, Nagaoka A, et al. Glycogen synthase kinase-3beta: a prognostic marker and a potential therapeutic target in human bladder cancer. Clin Cancer Res. 2010;16(21):5124-32.

7. Wang L, Zuo B, Xu D, Ren Z, Zhang H, Li X, et al. Alternative splicing of the porcine glycogen synthase kinase $3 \beta$ (GSK-33) gene with differential expression patterns and regulatory functions. PLoS One. 2012;7(7), e40250.

8. Miyashita K, Nakada M, Shakoori A, Ishigaki Y, Shimasaki T, Motoo Y, et al. An emerging strategy for cancer treatment targeting aberrant glycogen synthase kinase 3 beta. Anticancer Agents Med Chem. 2009;9(10):1114-22.

9. Ougolkov AV, Fernandez-Zapico ME, Bilim VN, Smyrk TC, Chari ST, Billadeau DD. Aberrant nuclear accumulation of glycogen synthase kinase-3beta in human pancreatic cancer: association with kinase activity and tumor dedifferentiation. Clin Cancer Res. 2006;12 (17):5074-81.

10. Phukan S, Babu VS, Kannoji A, Hariharan R, Balaji VN. GSK3beta: role in therapeutic landscape and development of modulators. Br J Pharmacol. 2010;160(1):1-19.

11. Marchand B, Tremblay I, Cagnol S, Boucher MJ. Inhibition of glycogen synthase kinase-3 activity triggers an apoptotic response in pancreatic cancer cells through JNK-dependent mechanisms. Carcinogenesis. 2012;33(3):529-37.

12. Hattermann K, Mentlein R. An Infernal Trio: The chemokine CXCL12 and its receptors CXCR4 and CXCR7 in tumor biology. Ann Anat. 2013;195(2):103-10.

13. Lekstan A, Olakowski M, Jabłońska B, Labuzek K, Olakowska E, Filip I, et al. Concentration of gelatinases and their tissue inhibitors in pancreatic inflammatory and neoplastic tumors and their influence on the early postoperative course. Pol Przegl Chir. 2013;85(2):65-72.

14. Durlik M, Gardian K. Metalloproteinase 2 and 9 activity in the development of pancreatic cancer. Pol Przegl Chir. 2012;84(8):377-82.

15. Luo G, Long J, Cui X, Xiao Z, Liu Z, Shi S, et al. Highly lymphatic metastatic pancreatic cancer cells possess stem cell-like properties. Int J Oncol. 2013;42(3):979-84.

16. Wang H, Rana S, Giese N, Büchler MW, Zöller M. Tspan8, CD44v6 and alpha6beta4 are biomarkers of migrating pancreatic cancer-initiating cells. Int J Cancer 2013;doi: 10.1002/ijc.28044.

17. Zhou W, Wang L, Gou SM, Wang TL, Zhang M, Liu T, et al. ShRNA silencing glycogen synthase kinase-3 beta inhibits tumor growth and angiogenesis in pancreatic cancer. Cancer Lett. 2012;316(2):178-86. 
18. Kim YS, Noh MY, Kim JY, Yu HJ, Kim KS, Kim SH, et al. Direct GSK-3 $\beta$ inhibition enhances mesenchymal stromal cell migration by increasing expression of $\beta$-PIX and CXCR4. Mol Neurobiol. 2013;47(2):811-20.

19. Dimova N, Wysoczynski M, Rokosh G. Stromal cell derived factor-1a promotes C-Kit + cardiac stem/progenitor cell quiescence through casein kinase 1a and GSK3ß. Stem Cells. 2014;32(2):487-99.

20. Tamura M, Sato MM, Nashimoto M. Regulation of CXCL12 expression by canonical Wnt signaling in bone marrow stromal cells. Int J Biochem Cell Biol. 2011;43(5):760-7.

21. Pan F, Ma SJ, Cao W, Liu H, Chen F, Chen X, et al. SDF-1a upregulation of MMP-2 is mediated by p38 MAPK signaling in pancreatic cancer cell lines. Mol Biol Rep. 2013;40(7):4139-46.

22. Kitagishi Y, Kobayashi M, Kikuta K, Matsuda S. Roles of PI3K/AKT/GSK3/mTOR Pathway in Cell Signaling of Mental IIInesses. Depress Res Treat. 2012;2012(752563)

23. Watson RL, Spalding AC, Zielske SP, Morgan M, Kim AC, Bommer GT, et al. GSK3beta and beta-catenin modulate radiation cytotoxicity in pancreatic cancer. Neop;asia. 2010;12(5):357-65.

24. Gaisina IN, Gallier F, Ougolkov AV, Kim KH, Kurome T, Guo S, et al. From a natural product lead to the identification of potent and selective benzofuran-3-yl-(indol-3-yl)maleimides as glycogen synthase kinase 3 beta inhibitors that suppress proliferation and survival of pancreatic cancer cells. J Med Chem. 2009;52(7):1853-63.

25. Jiang PH, Motoo Y, Sawabu N, Minamoto T. Effect of gemcitabine on the expression of apoptosis-related genes in human pancreatic cancer cells. Worl J Gastroenterol. 2006;12(10):1597-602.

26. Kitano A, Shimasaki T, Chikano Y, Nakada M, Hirose M, Higashi T, et al. Aberrant glycogen synthase kinase $3 \beta$ is involved in pancreatic cancer cell invasion and resistance to therapy. PLoS One. 2013;8(2), e55289.

27. Ou YQ, Zhu W, Li Y, Qiu PX, Huang YJ, Xie J, et al. Aspirin inhibits proliferation of gemcitabine-resistant human pancreatic cancer cells and augments gemcitabine-induced cytotoxicity. Acta Pharmacol Sin. 2010;31(1):73-80.

28. Ristorcelli E, Beraud E, Mathieu S, Lombardo D, Verine A. Essential role of Notch signaling in apoptosis of human pancreatic tumoral cells mediated by exosomal nanoparticles. Int J Cancer. 2009;125(5):1016-26.

29. Shimasaki T, Ishigaki $Y$, Nakamura $Y$, Takata T, Nakaya N, Nakajima $H$, et al. Glycogen synthase kinase $3 \beta$ inhibition sensitizes pancreatic cancer cells to gemcitabine. J Gastroenterol. 2012:47(3):321-33.

30. Shimasaki T, Kitano A, Motoo Y, Minamoto T. Aberrant glycogen synthase kinase $3 \beta$ in the development of pancreatic cancer. J Carcinog. 2012;doi: 10.4103/1477-3163.100866.

31. Johnson JL, Rupasinghe S, Stefani F, Schuler MA, Gonzalez de Mejia E. Citrus flavonoids luteolin, apigenin, and quercetin inhibit glycogen synthase kinase-3 $\beta$ enzymatic activity by lowering the interaction energy within the binding cavity. J Med Food. 2011;14(4):325-33.

32. Billadeau DD. Primers on molecular pathways. The glycogen synthase kinase-3beta. Pancreatology. 2007:7(5-6):398-402.

33. Garcea G, Manson MM, Neal CP, Pattenden CJ, Sutton CD, Dennison AR, et al. Glycogen synthase kinase-3 beta; a new target in pancreatic cancer? Curr Cancer Drug Targets. 2007;7(3):209-15.

34. Wilson 3rd W, Baldwin AS. Maintenance of constitutive IkappaB kinase activity by glycogen synthase kinase-3alpha/beta in pancreatic cancer. Cancer Res. 2008;68(19):8156-63.

35. Al-Aynati MM, Radulovich N, Riddell RH, Tsao MS. Epithelial-cadherin and beta-catenin expression changes in pancreatic intraepithelial neoplasia. Clin Cancer Res. 2004;10(4):1235-40.

36. Lapid K, Itkin T, D'Uva G, Ovadya Y, Ludin A, Caglio G, et al. GSK3 $\beta$ regulates physiological migration of stem/progenitor cells via cytoskeletal rearrangement. J Clin Invest. 2013;123(4):1705-17.

37. Liu Z, Habener JF. Stromal cell-derived factor-1 promotes survival of pancreatic beta cells by the stabilisation of beta-catenin and activation of transcription factor 7-like 2 (TCF7L2). Diabetologia. 2009;52(8):1589-98.

38. Rihua Zhang XP, Huang Z, Weber GF, Zhang G. Osteopontin Enhances the Expression and Activity of MMP-2 via the SDF-1/CXCR4 Axis in Hepatocellular Carcinoma Cell Lines. PLoS One. 2011;6(8), e23831.

\section{Submit your next manuscript to BioMed Central and take full advantage of:}

- Convenient online submission

- Thorough peer review

- No space constraints or color figure charges

- Immediate publication on acceptance

- Inclusion in PubMed, CAS, Scopus and Google Scholar

- Research which is freely available for redistribution

Submit your manuscript at www.biomedcentral.com/submit 